\title{
Relative contribution of biotic and abiotic factors to the population density of the cassava green mite, Mononychellus tanajoa (Acari: Tetranychidae)
}

\author{
Adriano S. Rêgo • Adenir V. Teodoro • Anilde G. S. Maciel • \\ Renato A. Sarmento
}

Received: 16 May 2012/ Accepted: 31 January 2013/Published online: 17 February 2013

(C) Springer Science+Business Media Dordrecht 2013

\begin{abstract}
The cassava green mite, Mononychellus tanajoa, is a key pest of cassava, Manihot esculenta Crantz (Euphorbiaceae), and it may be kept in check by naturally occurring predatory mites of the family Phytoseiidae. In addition to predatory mites, abiotic factors may also contribute to regulate pest mite populations in the field. Here, we evaluated the population densities of both $M$. tanajoa and the generalist predatory mite Euseius ho DeLeon (Acari: Phytoseiidae) over the cultivation cycle (11 months) of cassava in four study sites located around the city of Miranda do Norte, Maranhão, Brazil. The abiotic variables rainfall, temperature and relative humidity were also recorded throughout the cultivation cycle of cassava. We determined the relative importance of biotic (density of $E$. ho) and abiotic (rainfall, temperature and relative humidity) factors to the density of $M$. tanajoa. The density of $M$. tanajoa increased whereas the density of $E$. ho remained constant throughout time. A hierarchical partitioning analysis revealed that most of the variance for the density of $M$. tanajoa was explained by rainfall and relative humidity followed by $E$. ho density and temperature. We conclude that abiotic factors, especially rainfall, were the main mechanisms driving $M$. tanajoa densities.
\end{abstract}

Keywords Biological control $\cdot$ Pest mite $\cdot$ Predatory mites $\cdot$ Population dynamics

\footnotetext{
A. S. Rêgo · A. V. Teodoro · A. G. S. Maciel

Graduate Programme in Agroecology, Maranhão State University (UEMA), PO Box 09, São Luís, MA, Brazil
}

\author{
A. V. Teodoro $(\bowtie)$ \\ Embrapa Coastal Tablelands, Av. Beira-Mar 3250, Jardins, PO Box 44, Aracaju, SE, Brazil \\ e-mail: adenir.teodoro@embrapa.br
}

\section{R. A. Sarmento}

Graduate Programme in Plant Science, Federal University of Tocantins (UFT), PO Box 66, Gurupi, TO, Brazil 


\section{Introduction}

Cassava, Manihot esculenta Crantz (Euphorbiaceae), is cultivated in many tropical and subtropical regions of the world and it is considered one of the most important staple food sources for smallholders (Henry and Hershey 2002; Suja et al. 2010).

The cassava green mite, Mononychellus tanajoa (Bondar) (Acari: Tetranychidae), is a key pest of cassava in northeastern Brazil (Moraes and Flechtmann 2008). The biological control of phytophagous mites is considered an important environmental service carried out by natural enemies such as predatory mites, especially those belonging to the family Phytoseiidae. Phytoseiids have the ability to suppress populations of pest mites, mainly tetranychids (Colfer et al. 2004; Sarmento et al. 2011). The indigenous predatory mite Typhlodromalus aripo De Leon (Acari: Phytoseiidae) is the most effective biological control agent of M. tanajoa in Brazil and in Africa where it was introduced in the 1990s (Onzo et al. 2003, 2005). However, generalist predatory mites may also contribute to the regulation of pest mite populations in the field (McMurtry and Croft 1997; Sarmento et al. 2011). Predatory mite species belonging to the genus Euseius (Acari: Phytoseiidae) are classified as generalists specialised in the use of pollen and other alternative foods besides preying on pest mites (McMurtry and Croft 1997; Croft et al. 2004).

In addition to natural enemies, the seasonal variation of abiotic factors such as rainfall, temperature and relative humidity affects both the distribution and population density of arthropods in the field (Yaninek et al. 1989; Hanna et al. 2005; Onzo et al. 2005; Teodoro et al. 2008; Zundel et al. 2009).

Here, we determined the relative importance of biotic (density of a common generalist predatory mite found inhabiting cassava plants in the study region-Euseius ho DeLeon) and abiotic (rainfall, temperature and relative humidity) factors to the density of M. tanajoa.

\section{Materials and methods}

Study region and mite sampling

The study was conducted in four study sites located around the city of Miranda do Norte $\left(3^{\circ} 36^{\prime} 45^{\prime \prime} \mathrm{S}, 4^{\circ} 34^{\prime} 08^{\prime \prime} \mathrm{W}, 44 \mathrm{~m}\right.$ above sea level), Maranhão, Brazil. No agrochemicals were used in any study site and the minimum distance between sites was approximately $1 \mathrm{~km}$. The predatory mite $E$. ho is a common generalist phytoseiid species inhabiting cassava plants in the study region (Rêgo Unpublished data). In each study site, we randomly chose 10 cassava plants located at least 10 meters from field boundaries to avoid edge effects. We evaluated six fully expanded leaves per cassava plant (two leaves from each part, i.e., top, medium and bottom) totaling 60 leaves per study site. We did not attempt to record the predatory mite $T$. aripo since this phytoseiid inhabits the apex (growing point) of cassava (Onzo et al. 2003) and our evaluations were conducted only on fully expanded cassava leaves. The numbers of $M$. tanajoa and $E$. ho (all stages pooled, i.e., eggs, larvae, nymphs and adults) were recorded using a binocular microscope (Stemi DV4, Zeiss, Germany) at monthly intervals over the cultivation cycle of cassava (from February to December 2009).

The numbers of both $M$. tanajoa and $E$. ho per leaf were converted into mites per $\mathrm{cm}^{2}$ as cassava leaves widely vary in size and number of lobes throughout the cultivation cycle. Leaf areas were calculated by randomly choosing 15 cassava leaves per study site per month and drawing their outlines on a paper which was subsequently cut out and weighed. A paper of 
known area $\left(1 \mathrm{~cm}^{2}\right)$ was cut out and weighed in an analytic scale (Model BL320H, Shimadzu, Brazil) to estimate the number of grams per $\mathrm{cm}^{2}$. The estimated area per plant was obtained by multiplying the number of sampled leaves by the average area for each study site per month. Subsequently, the densities of both $M$. tanajoa and $E$. ho per $\mathrm{cm}^{2}$ were obtained by the ratio between the number of mites per plant and the estimated area.

\section{Abiotic factors}

Temperature and relative humidity were monthly recorded throughout the cultivation cycle of cassava under standardized conditions (on sunny days between 08:00 and 10:00 and in the center of each study site to avoid edge effects) using a digital thermohygrometer (Model 910.15 CHP, Alla, Brazil) placed on the ground for 10 min. Rainfall data was obtained through interpolation from the database of the National Institute for Space Research (INPE) (http://www6.cptec.inpe.br/proclima/).

\section{Statistical analyses}

A repeated measures Anova with type I sequential sums of squares was performed to compare the densities of $M$. tanajoa and $E$. ho over the cultivation cycle of cassava. Oneway Anovas followed by post hoc Tukey tests were conducted to compare the densities of both mite species within each month. All analyses were carried out using Statistica 7.0 (StatSoft Inc.1984-2004). A hierarchical partitioning analysis was used to assess the relative contribution of biotic (density of $E$. ho) and abiotic factors (rainfall, temperature and relative humidity) to the density of $M$. tanajoa by estimating the percentage of explained variance of each predictor variable, considering all possible models in a multivariate regression (Heikkinen et al. 2005). The hierarchical partitioning analysis was conducted with the R statistical package (Mc Nally and Walsh 2004) using the "hier.part and gtools packages" (R 2.10.1, R Development Core Team 2010). Linear regressions between densities of M. tanajoa and biotic and abiotic factors were performed using SigmaPlot 11.0 (Systat Software Inc 2008). Population densities of M. tanajoa and E. ho were $\log \mathrm{x}+1$ transformed to achieve assumptions of a normal distribution.

\section{Results}

The cassava green mite $M$. tanajoa had a higher population density $(0.138 \pm 0.011$ mites/ $\left.\mathrm{cm}^{2}\right)$ compared to the predatory mite $E$. ho $\left(0.001 \pm 0.0002 \mathrm{mites} / \mathrm{cm}^{2}\right)\left(\mathrm{F}_{1.78}=251.96\right.$, $P<0.05)$. The population density of $M$. tanajoa increased with higher population levels being attained in the dry season (July-December) while the density of $E$. ho remained constant over the cultivation cycle of cassava (Fig. $1 ; \mathrm{F}_{10.780}=11.227, P<0.05$ ). Except for February and April, the population density of $M$. tanajoa was higher than the density of $E$. ho throughout the cultivation cycle of cassava (Fig. 1; Feb: $\mathrm{F}_{1.78}=0.001, P>0.05$; Mar: $\mathrm{F}_{1.78}=4.835, P<0.05 ;$ Apr: $\mathrm{F}_{1.78}=3.819, \quad P>0.05 ;$ May: $\mathrm{F}_{1.78}=8.310$, $P<0.01$; Jun: $\mathrm{F}_{1.78}=13.122, P<0.0001 ;$ Jul: $\mathrm{F}_{1.78}=25.208, P<0.0001$; Aug: $\mathrm{F}_{1.78}=32.097, P<0.0001 ;$ Sep: $\mathrm{F}_{1.78}=18.641, P<0.0001 ;$ Oct: $\mathrm{F}_{1.78}=29.957$, $P<0.0001$; Nov: $\mathrm{F}_{1.78}=52.363, P<0.0001$; Dec: $\left.\mathrm{F}_{1.78}=32.075, P<0.0001\right)$.

The abiotic factor rainfall explained most of the variance $(54.0 \%)$ for the density of $M$. tanajoa, followed by relative humidity $(12.1 \%)$, density of $E$. ho (4.9\%) and temperature $(1.0 \%)$ according to hierarchical partitioning. 


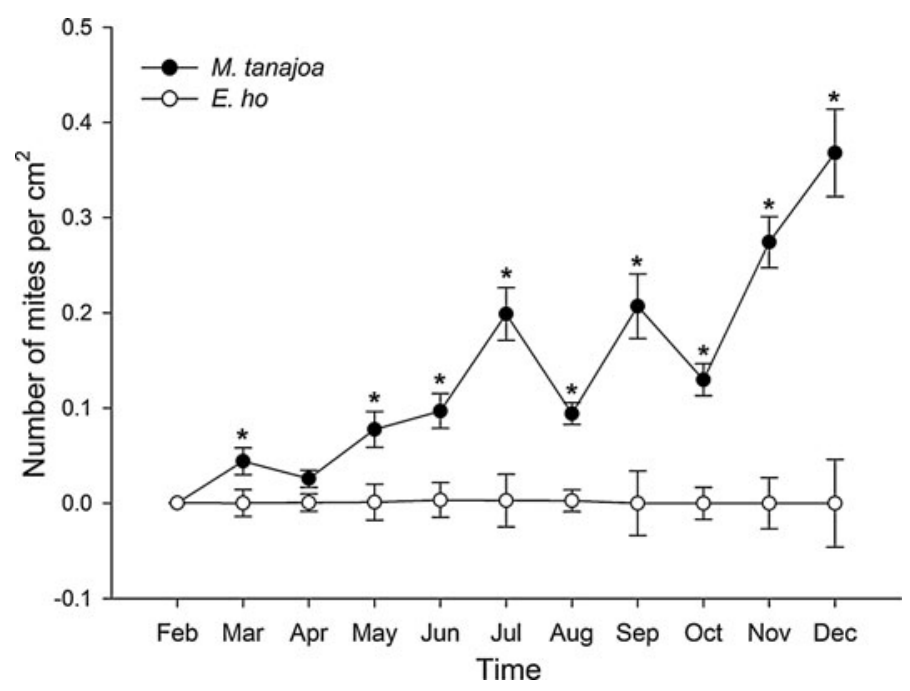

Fig. 1 Population densities of Mononychellus tanajoa and Euseius ho over the cultivation cycle of cassava. Mean \pm SE are shown. Asterisks represent significant differences between densities of M. tanajoa and E. ho within each month based on one-way Anovas $(P<0.05)$. $\log \mathrm{x}+1$ transformed data

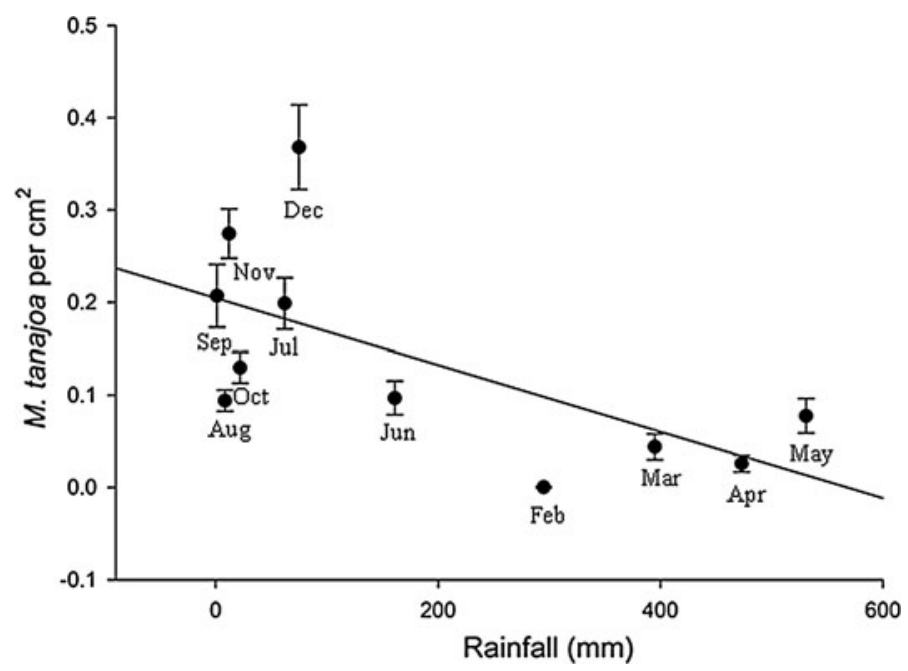

Fig. 2 Relationship between population density of Mononychellus tanajoa and monthly total rainfall throughout the cultivation cycle of cassava $\left(\mathrm{y}=0.204-0.0004 \mathrm{x}, \mathrm{F}_{1.9}=6.383, \mathrm{R}^{2}=0.415, P<0.05\right) . \mathrm{Log}$ $\mathrm{x}+1$ transformed data

The density of $M$. tanajoa linearly decreased with increasing rainfall (Fig. 2; $\left.\mathrm{F}_{1.9}=6.383, \mathrm{R}^{2}=0.415, P<0.05\right)$ confirming results from hierarchical partitioning. Densities of $M$. tanajoa, however, were not related to relative humidity $\left(\mathrm{F}_{1.9}=0.016\right.$, $\left.\mathrm{R}^{2}=0.001, P>0.05\right)$, density of $E$. ho $\left(\mathrm{F}_{1.9}=0.315, \mathrm{R}^{2}=0.033, P>0.05\right)$ and temperature $\left(\mathrm{F}_{1.9}=0.007, \mathrm{R}^{2}=0.0001, P>0.05\right)$. 


\section{Discussion}

The main mechanisms influencing population densities of $M$. tanajoa were abiotic factors. Rainfall explained the highest fraction of variance for the population density of M. tanajoa. This was expected since the study area is characterised by heavy rains during the wet season (average of $348.5 \mathrm{~mm} / \mathrm{month}$ from January to June 2009). Furthermore, we found a negative correlation between the density of $M$. tanajoa and rainfall confirming results from hierarchical partitioning. This negative relationship might be due to the fact that washing mite colonies off leaves as a result of heavy rains might have outweighed an increased number of mites supported by new foliage production fostered by early rains (Yaninek et al. 1989). Likewise, Onzo et al. (2005) and Hanna et al. (2005) found that the abundance of $M$. tanajoa decreased in periods of high rainfall.

The abiotic factor relative humidity also explained large portions of the variance for densities of $M$. tanajoa. Indeed, an average of $80 \%$ relative humidity throughout the cultivation cycle of cassava was found in the study sites. Relative humidity is an important climatic factor that influences the occurrence of arthropods in the field (Zundel et al. 2009). Bonato et al. (1995), studying the effects of relative humidity on the cassava green mite M. progresivus Doreste and the cotton red mite Oligonychus gossypii (Zacher) in cassava fields found that relative humidity values below $30 \%$ and above $90 \%$ negatively affected the development, fecundity and survival of both species of mites.

The smallest fractions of the variance for the population density of $M$. tanajoa were explained by temperature followed by $E$. ho densities. The study area is characterised by low temperature variation over the year. Moreover, it is common in the study region temperatures above $30{ }^{\circ} \mathrm{C}$ during the dry season (July-December), which are ideal for tetranychid mites build up. Densities of $E$. ho were lower and remained constant throughout the cultivation cycle of cassava suggesting that this predator was unable to respond to the increasing populations of $M$. tanajoa over this period. Indeed, the density of $E$. ho explained $<5 \%$ of the density of $M$. tanajoa according to hierarchical partitioning. The mites of the genus Euseius are considered generalist predators specialised on pollen and other alternative foods besides feeding on pest mites (McMurtry and Croft 1997; Croft et al. 2004). Preliminary laboratory observations revealed that $E$. ho completes its cycle when fed M. tanajoa, but not when fed cassava pollen (Rêgo Unpublished data). This is intriguingly and more studies are needed to elucidate the importance of this generalist predator on the biological control of $M$. tanajoa and the role of alternative food in cassava fields.

Our results indicate that the population density of $M$. tanajoa was influenced over the course of cultivation cycle of cassava mainly by abiotic factors, especially rainfall.

Acknowledgments We thank Esther A. Silva for the identification of the predatory mite and the smallholders for their permission to carry out experiments on their farms. Funding was provided by "PNPD/ CAPES (PNPD0132080)", “CNPq (474994/2009-0)" and "FAPEMA (APP-00991/09)".

\section{References}

Bonato O, Mapangou-Divassa S, Gutierrez J (1995) Influence of relative humidity on life history parameters of Mononychellus progresivus and Oligonychus gossypii (Acari: Tetranychidae). Popul Ecol 24:841-845

Colfer RG, Rosenheim JA, Godfrey LD, Hsu CL (2004) Evaluation of large-scale releases of western predatory mite for spider mite control in cotton. Biol Control 30:1-10 
Croft BA, Blackwood JS, McMurtry JA (2004) Classifying life-style types of phytoseiid mites: diagnostic traits. Exp Appl Acarol 33:247-260

Hanna R, Onzo A, Lingeman R, Sabelis MW, Yaninek JS (2005) Seasonal cycles and persistence of an acarine predator-prey system on cassava in Africa. Pop Ecol 47:107-117

Heikkinen RK, Luoto M, Kuussaari M, Pöyry J (2005) New insights into butterfly-environment relationships using partitioning methods. Proc R Soc B 272:2203-2210

Henry G, Hershey C (2002) Cassava in South America and the Caribbean. In: Hillocks RJ, Tresh JM, Bellotti AC (eds) Cassava: biology, production and utilization. CABI Publishing Oxon, UK and New York, pp 17-40

Mc Nally R, Walsh CJ (2004) Hierarchical partitioning public-domain software. Biodivers Conserv 13:659-660

McMurtry JA, Croft BA (1997) Life styles of phytoseiid mites and their roles in biological control. Annu Rev Entomol 42:291-321

Moraes GJ, Flechtmann CHW (2008) Manual de Acarologia: acarologia básica e ácaros de plantas cultivadas no Brasil. Holos, Ribeirão Preto

Onzo A, Hanna R, Zannou I, Sabelis MW, Yaninek JS (2003) Dynamics of refuge use: diurnal, vertical migration by predatory and herbivorous mites within cassava plants. Oikos 101:59-69

Onzo A, Hanna R, Sabelis MW, Yaninek JS (2005) Temporal and spatial dynamics of an exotic predatory mite and its herbivorous mite prey on cassava in Benin, West Africa. Environ Entomol 34:866-874

R Development Core Team (2010) R: a language and environment for statistical computing. R foundation for statistical computing. http://www.R-project.org. Vienna, Austria

Sarmento RA, Rodrigues DM, Faraji F, Erasmo EAL, Lemos F, Teodoro AV, Kikuchi WT, Santos GR, Pallini A (2011) Suitability of the predatory mites Iphiseiodes zuluagai and Euseius concordis in controlling Polyphagotarsonemus latus and Tetranychus bastosi on Jatropha curcas plants in Brazil. Exp Appl Acarol 53:203-214

StatSoft Inc. (1984-2004) Statistica for windows (software-system for data-analyses), version 7.0. Tulsa, USA

Suja G, John SK, Sreekumar J, Srinivas T (2010) Short-duration cassava genotypes for crop diversification in the humid tropics: growth dynamics, biomass, yield and quality. J Sci Food Agric 90:188-198

Teodoro AV, Klein AM, Tscharntke T (2008) Environmentally mediated coffee pest densities in relation to agroforestry management, using hierarchical partitioning analyses. Agric Ecosyst Environ 125:120-126

Systat Software Inc (2008) SigmaPlot for windows (development and testing procedures), version 11.0, Germany

Yaninek JS, Herren HR, Gutierrez AP (1989) Dynamics of Mononychellus tanajoa (Acari: Tetranychidae) in Africa: seasonal factors affecting phenology and abundance. Environ Entomol 18:625-632

Zundel C, Nagel P, Hanna R, Korner F, Scheidegger U (2009) Environment and host-plant genotype effects on the seasonal dynamics of a predatory mite on cassava in sub-humid tropical Africa. Agric For Entomol 11:321-331 